Part of Journal of Research of the National Bureau of Standards, Volume 18, February 1937

\title{
DETERMINATION OF SULPHUR OCCURRING AS SULPHIDE IN PORTLAND CEMENT
}

\author{
By Harry A. Bright
}

ABSTRACT

A modification of the usual evolution method for the determination of sulphur is described wherein stannous chloride is used during solution of the sample to prevent the oxidation of hydrogen sulphide by the higher oxides of manganese and iron.

\section{CONTENTS}

I. Introduction Page

II. Procedure

III. Experimental results _..

\section{INTRODUCTION}

Among the minor constituents of certain portland cements are small amounts of sulphides associated with compounds of manganese and iron. The manganese is usually in valence states higher than 2 and interferes with any determination of sulphides based on the amount of hydrogen sulphide that is evolved when a sample is dissolved in hydrochloric acid. Ferric iron, which is practically always present in portland cements, likewise interferes. Sulphides and higher oxides of manganese in portland cement may seem incompatible, but both may be present, particularly in blended cements.

Watson ${ }^{1}$ has recommended the use of stannous chloride to overcome the effect of ferric iron. Stannous chloride for this purpose was independently used at this Bureau in connection with an investigation on the reducing and oxidizing constituents of cements. As will be shown later, it was found that the addition of this salt also prevented interference by higher oxides of manganese. Titanous chloride and zinc dust were not as efficient as stannous chloride. The procedure developed at this Bureau is given in section II.

\section{PROCEDURE}

Transfer $5 \mathrm{~g}$ of the sample to a dry 500-ml flask and connect the latter as shown in figure 1. Place $15 \mathrm{ml}$ of an ammoniacal solution of zinc sulphate and $285 \mathrm{ml}$ of distilled water in the tall-form beaker. ${ }^{2}$

1 Cement 5, 49 (1932).

2 For very small amounts of sulphides, an ammoniacal solution of $\mathrm{CdCl}_{2}$ can be substituted, as the yellow CdS facilitates detection of traces of sulphides. 
Add $10 \mathrm{ml}$ of water through the thistle tube, and shake the flask to wet the cement completely. Add $25 \mathrm{ml}$ of stannous chloride solution, shake several times to mix, and then add $65 \mathrm{ml}$ of diluted hydrochloric acid $(10+3)$. Connect the inlet tube, pass a slow stream of

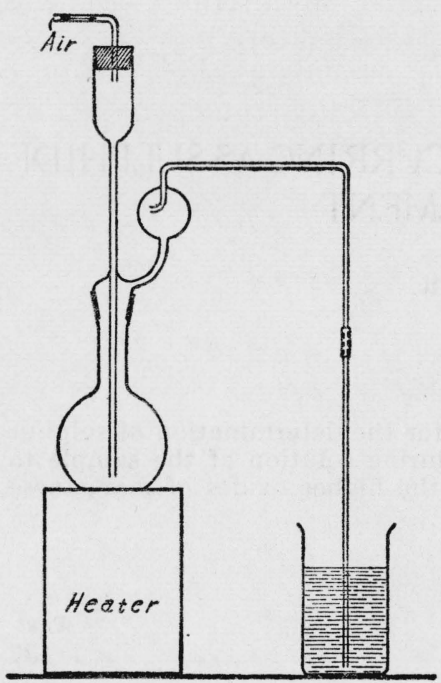

Figure 1.-Apparatus for the determination of sulphide sulphur. air ${ }^{3}$ through the system, and heat the flask and contents slowly until boiling ensues. Boil gently for 5 to 6 minutes, cut off the heat and continue the passage of air for 3 to 4 minutes. Disconnect the delivery tube, and leave it in the solution for use as a stirrer. ${ }^{4}$ Add $2 \mathrm{ml}$ of starch solution and then $40 \mathrm{ml}$ of diluted hydrochloric acid $(1+1)$. Titrate immediately with the iodate solution until a permanent blue color is obtained. Subtract the blank obtained with the reagents alone, and calculate the percentage of sulphur.

Ammoniacal zinc sulphate.-Dissolve $50 \mathrm{~g}$ of $\mathrm{ZnSO}_{4} .7 \mathrm{H}_{2} \mathrm{O}$ in $150 \mathrm{ml}$ of water and $350 \mathrm{ml}$ of $\mathrm{NH}_{4} \mathrm{OH}$ (sp gr 0.90). Let stand 24 hours and filter.

Stannous chloride.-To $10 \mathrm{~g}$ of $\mathrm{SnCl}_{2} \cdot 2 \mathrm{H}_{2} \mathrm{O}$, in a small flask, add $7 \mathrm{ml}$ of diluted $\mathrm{HCl}(1+1)$. Warm gently until the salt is dissolved. Cool, and add $95 \mathrm{ml}$ of water. This reagent should be made up daily as needed,

as the salt tends to hydrolyze.

Starch solution.-To $500 \mathrm{ml}$ of boiling distilled water, add a cold suspension of $5 \mathrm{~g}$ of soluble starch in $25 \mathrm{ml}$ of distilled water, cool, add a cool solution of $5 \mathrm{~g}$ of $\mathrm{NaOH}$ in $50 \mathrm{ml}$ of distilled water, then add $15 \mathrm{~g}$ of KI, and mix thoroughly.

Potassium iodate.- $(0.03 N)$ Dissolve $1.12 \mathrm{~g}$ of $\mathrm{KIO}_{3}$ and $12 \mathrm{~g}$ of $\mathrm{KI}$ in $1,000 \mathrm{ml}$ of distilled water. Standardize by means of sodium oxalate through $\mathrm{KMnO}_{4}$ and $\mathrm{Na}_{2} \mathrm{~S}_{2} \mathrm{O}_{3}$ as follows: To $300 \mathrm{ml}$ of water in a 500-ml flask, preferably glass-stoppered, add $10 \mathrm{ml}$ of hydrochloric acid (sp gr 1.18) and $1 \mathrm{~g}$ of KI. Cool and add $25 \mathrm{ml}$ of $0.03 \mathrm{~N} \mathrm{KMnO}_{4}$ solution which has been standardized against sodium oxalate. Swirl gently, stopper, and let stand for 5 minutes. Titrate the liberated iodine with thiosulphate solution (approximately $0.03 N$ ) until the color nearly fades. Then add $2 \mathrm{ml}$ of starch solution and continue the titration until the blue color is just destroyed. In another flask, repeat the experiment with the sole difference that $25 \mathrm{ml}$ of the iodate solution is substituted for the standard permanganate solution. The normality of the iodate solution is then found by dividing the volume of $\mathrm{Na}_{2} \mathrm{~S}_{2} \mathrm{O}_{3}$ solution required in the second titration by the

${ }^{3}$ Tests indicated that the substitution of hydrogen for air offers no advantages in this particular determination.

- If the absorbing solution has warmed up during the evolution, cool it to 20 to $25^{\circ} \mathrm{C}$. 
volume required in the first, and multiplying by the normality factor of the $\mathrm{KMnO}_{4}$ solution. One $\mathrm{ml}$ of $N \mathrm{KMnO}_{4}=0.01603 \mathrm{~g}$ of sulphur.

\section{EXPERIMENTAL RESULTS}

The accuracy of the procedure was tested on mixtures of $\mathrm{CaO}$, $\mathrm{MnO}_{2}, \mathrm{Fe}_{2} \mathrm{O}_{3}$, and an amount of $\mathrm{ZnS}$ approximately equivalent to the amount of sulphides that may occur in cements. Lime was used in these mixtures because an iron-free portland cement was not available. The results obtained are given in table 1.

TABLE 1.-Determination of sulphide-sulphur in synthetic mixtures

\begin{tabular}{|c|c|c|c|c|c|}
\hline \multirow{2}{*}{$\mathrm{ZnS}$} & \multirow{2}{*}{$\mathrm{CaO}$} & \multirow{2}{*}{$\mathrm{MnO}_{2}$} & \multirow{2}{*}{$\mathrm{Fe}_{2} \mathrm{O}_{3}$} & \multicolumn{2}{|c|}{ Sulphide-sulphur } \\
\hline & & & & Added a & Found \\
\hline$\stackrel{\stackrel{g}{g}}{0.0085}$ & $\mathrm{~g}$ & $\mathrm{~g}$ & $\mathrm{~g}$ & g & $\stackrel{\mathrm{g}}{0.0027}$ \\
\hline $\begin{array}{l}.0057 \\
.0052 \\
.0084 \\
.0080 \\
.0054\end{array}$ & $\begin{array}{l}3.3 \\
3.3 \\
3.3 \\
3.3 \\
3.3\end{array}$ & $\begin{array}{l}0.09 \\
.09 \\
.09 \\
.09\end{array}$ & 0.25 & $\begin{array}{l}0.00187 \\
.0017_{9} \\
.0027_{5} \\
.0026_{2} \\
.0017_{7}\end{array}$ & $\begin{array}{c}.0018_{8} \\
.0016_{6} \\
.0027 \\
.00262 \\
(b)\end{array}$ \\
\hline
\end{tabular}

- Calculated on the basis of 99.6 percent $\mathrm{ZnS}$.

$\checkmark$ None found; no $\mathrm{SnCl}_{2}$ added.

The procedure was also applied to several sulphide-bearing portland cements of low manganese content, and to mixtures of these with a cement having a high manganese content. When treated with concentrated hydrochloric acid, $1 \mathrm{~g}$ of this cement (labeled $A$ in the table) liberated $0.006 \mathrm{~g}$ of chlorine per gram, which is in excess of what should be liberated if the manganese were all present in the trivalent state. If all of this chlorine should react with hydrogen sulphide $\left(\mathrm{H}_{2} \mathrm{~S}+\mathrm{Cl}_{2}=2 \mathrm{HCl}+\mathrm{S}\right)$, it would destroy $0.0027 \mathrm{~g}$ of "sulphide" sulphur. In tests with mixtures of zine sulphide and the cement it was found that the amount actually destroyed in the evolution method (without stannous chloride) was approximately half theoretical, or about $0.001 \mathrm{~g}$ of "sulphide" sulphur per gram of the cement.

The results obtained, together with those obtained in tests in which no $\mathrm{SnCl}_{2}$ was used, were as follows:

$5 \mathrm{~g}$ of cement $A(0.72 \% \mathrm{Mn})$

Iodate $\mathrm{ml}$ Sulphur (\%)

$2 \mathrm{~g}$ of cement $B\left(5.0 \% \mathrm{Fe}_{2} \mathrm{O}_{3} ; 0.10 \% \mathrm{Mn}\right) \ldots$

$0.000_{3}$

$2 \mathrm{~g}$ of cement $B+3 \mathrm{~g}$ of cement $A$

5.98

.149

$2 \mathrm{~g}$ of cement $B$ (no $\mathrm{SnCl}_{2}$ added)

1. 23

.150

.031

$2 \mathrm{~g}$ of cement $C\left(5.3 \% \mathrm{Fe}_{2} \mathrm{O}_{3} ; 0.10 \% \mathrm{Mn}\right) \ldots \ldots \ldots \ldots$

$2 \mathrm{~g}$ of cement $C+3 \mathrm{~g}$ of cement $A$

1. 71

.043

$2 \mathrm{~g}$ of cement $C$ (no $\mathrm{SnCl}_{2}$ added)

.78

.020

$4 \mathrm{~g}$ of cement $D\left(0.3 \% \mathrm{Fe}_{2} \mathrm{O}_{3} ; 0.01 \% \mathrm{Mn}\right)$

1. 10

.014

$4 \mathrm{~g}$ of cement $D+3 \mathrm{~g}$ of cement $A$

1. 18

$4 \mathrm{~g}$ of cement $D$ (no $\mathrm{SnCl}_{2}$ added)

$4 \mathrm{~g}$ of cement $D+3 \mathrm{~g}$ of cement $A$ (no $\mathrm{SnCl}_{2}$ added)

00

.015

.005

None

WAshington, October 24, 1936. 